\title{
IMPROVING SPEAKING SKILL OF THE TENTH GRADE STUDENTS OF SMK 17 AGUSTUS 1945 MUNCAR THROUGH DIRECT PRACTICE WITH THE NATIVE SPEAKER
}

\author{
Mohamad Nor Shodiq \\ Institut Agama Islam Darussalam (IAIDA) Banyuwangi \\ E-mail address: souldig_yep@yahoo.com
}

\begin{abstract}
The Classroom Action Research (CAR) aims to invent teaching and learning strategy which fits the learners' style and to solve the teachers' problem in finding the appropriate technique in teaching. The researcher took SMK 17 Agustus 1945 Muncar Banyuwangi on 35 students of the tenth grade of AK 1 and was conducted in one cycle with the phases of planning, implementing, observing, and reflecting. The researcher found that the implementation of Direct Practice with the Native Speaker could improve the students' speaking skill. It was proved by the result of the students' speaking score. The average classical score in preliminary study was 50. 00.They had improvement from the third meeting but did not all of students meet the criteria of success and were still below the KKM. In the fourth meeting was found that all of the students could reach criteria of success and KKM score as 70.00. Direct Practice with the Native Speaker creates the teaching and learning process fun, and good atmosphere of competition among the students.
\end{abstract}

\section{Keywords: Improving, Speaking Skill, Direct Practice, Native Speaker}

\begin{abstract}
Abstrak
Penelitian Tindakan Kelas (CAR) bertujuan untuk menemukan strategi belajar mengajar yang sesuai dengan gaya peserta didik dan untuk memecahkan masalah guru dalam menemukan teknik yang tepat dalam mengajar. Peneliti mengambil SMK 17 Agustus 1945 Muncar Banyuwangi pada 35 siswa kelas sepuluh AK 1 dan dilakukan dalam satu siklus dengan tahapan perencanaan, pelaksanaan, pengamatan, dan refleksi. Peneliti menemukan bahwa penerapan Praktek Langsung dengan Pembicara Asli dapat meningkatkan keterampilan berbicara siswa. Itu terbukti dari hasil nilai berbicara siswa. Skor klasik rata-rata dalam studi pendahuluan adalah 50.00. Mereka mengalami peningkatan dari pertemuan ketiga tetapi tidak semua siswa memenuhi kriteria keberhasilan dan masih di bawah KKM. Dalam pertemuan keempat ditemukan bahwa semua siswa dapat mencapai kriteria keberhasilan dan skor KKM sebagai 70.00. Praktek langsung dengan Pembicara Asli menciptakan proses belajar mengajar yang menyenangkan, dan suasana kompetisi yang baik di antara para siswa.
\end{abstract}

Kata Kunci: Peningkatan, Keterampilan Berbicara, Praktek Langsung, Penutur Asli 


\section{A. Introduction}

It is fair to say that throughout history foreign language learning has been a practical concern. Nowadays, the most widely studied foreign language is English, since it is an international language and it is spoken by many people everyday worldwide. As a foreign language learner of English, students are interested in what the speaker language do. As their competency increases, they find themselves getting more interested in knowing all about the English speaking and their life, their culture, their ideas, and everything about them. Including their history, but the first, most of students learning English as a foreign language expect to be able to speak this language, either to obtained information from the topics that are discussed or to enjoy them just as relaxation. This is also suitable for the statement "why do we communicate". And it is supported in the Koran (Ar- Rahman : 1-4) says that God Most Gracious ! It is He Who has taught the Koran. He has created man: He has taught him speech (And Intelligence).

For teaching speaking, there are 7 principles for teaching speaking skill; (1) Focus on both fluency and accuracy, depending on teachers' objective. (2) Provide intrinsically motivating technique. (3) Encourage the use of authentic language in meaningful contexts. (4) Provide appropriate feedback and correction. (5) Capitalize on the natural link between speaking and listening. (6) Give students opportunity to initiate oral communication and (7) Encourage the development of speaking strategies. Brown (2007, p. 331)

Based on Jalaludin Rakhmat in Psikologi Komunikasi (2007, p. 48- 78) denotes that the process of speaking consist of four stages:

First is Sensation, it is the first step in getting information. Based on Benyamin B. Wolman (1973:343) said that sensation is the elemental experience which does not need the verbal explain, symbolist, or conception, and mainly connects with the senses. The great philosophy, John Locke said "there is nothing in the mind except what was first in the senses.

Second Perception: a cognitive process by which visual impression become meaningful and in the light of the students' past experience and present needs involve understanding, comprehending, and organizing; and it is supported by Desideroto (1976: 129) said that the meaning of sense information does not 
influence sensation but also attention, expectation, motivation, and memory. Third is Memory, based on Schlesssinger and Groves (1976:352) said "the structural system, which causes organism able to record the fact about the world and uses the knowledge for guiding the behaviors".

Fourth is Conceptualization of thinking: a process where perception is classified in to the larger patterns that embrace classes or categories and thus it contributes further to abstract thinking and generalization. In the tenth grade of AK 1 at SMK 17 Agustus 1945 Muncar Banyuwangi, the fact is that the students have difficulties to improve their speaking skill because they always use their native language in their conversation in the classroom rather than English. Many students are nervous and shy when they asked to speak English and they do not have self-confidence to speak English. They worry about making mistake in speaking English. When the teacher asks them to speak, no body responds or they just responds to the teacher's order only with the familiar words or phrases such as: good morning, I am fine etc. They have lack motivation to practice English either with teacher or with their friends. The students often keep silent when teacher ask them to practice their English and they tend to use Indonesian or they speak with their native language. Those facts produce the low speaking test result, that is $40-50$ and those score are under the KKM of 70 . Those problems occur because of lack of vocabularies or they do not get used to speaking English before, and the teacher focuses to the grammatical without paying attention to the students' English speaking skill.

But the adjective direct has 10 senses: (1). Direct in spatial dimensions; proceeding without deviation or interruption; straight and short. (2) Having no intervening persons, agents, conditions. (3). Extended senses; direct in means or manner or behavior or language or action. (4).In a straight unbroken line of descent from parent to child. (5). Moving from west to east on the celestial sphere; or--for planets--around the sun in the same direction as the Earth. (6). Similar in nature or effect or relation to another quantity. (7). (of a current) flowing in one direction only. (8). Being an immediate result or consequence. (9).in precisely the same words used by a writer or speaker and (10). Lacking compromising or mitigating elements; exact. 
Meanwhile, based on practice (noun) states that the noun of practice has 5 senses: (1). A customary way of operation or behavior. (2). Systematic training by multiple repetitions. (3). Translating an idea into action. (4).The exercise of a profession and (5). Knowledge of how something is usually done.

Still based on http://www.audioenglish.net/dictionary/practice.htm states that the verb of practice has 4 senses: (1). Learn by repetition. (2). Avail oneself to. (3). Carry out or practice; as of jobs and professions and (4). Engage in a rehearsal (of). Based on the definition above, the researcher concluded that direct practice is an activity which is done by one individually or group to achieve their goal and done repeatedly.

Oxford Advanced Learner Dictionary defines that native is a person born in a place, country etc and associated with it birth, while states that Native speakers of English are people whose first language is English. They learned English when they were children. They think in English. They use it naturally. Usually native speakers of English are people from English-speaking countries like the USA, Great Britain, Australia, Canada, Ireland, etc.

From the references above, the writer concludes that native speakers of English are ones who born in some countries whose English is as their first language and they do not need to learn English because they learn it from their mother tongue.

\section{B. Method}

Based on the focus of the research that intends to improve students' speaking skill through direct practice with the native speaker. Therefore, CAR (Class Action Research) is as a design in this research. The researcher designed planning, implementing, observing, and reflecting.

\section{Planning}

The technique and the strategy which was applied is "direct practice". In general, the techniques are as follow: (1) introducing the direct practice, (2) practicing direct practice with the native speaker and (3) applying direct practice with native speakers. In this stage, the researcher described the application of direct practice to improve students' speaking skill. 
The first step, the researcher started the teaching learning process with greeting and checking list of students' presence. The teacher reminded the students about the importance of English especially speaking skill, and then asked students to sit with their peers to be ready to start the material about direct practice.

The second step, the researcher began with introducing and explaining about what the direct practice with native speaker was and how to apply direct practice with native speaker. Then, the students were given some examples of direct practice with native speaker by watching some videos about direct practice with native speaker in order that the students have at least visualization about direct practice with native speaker. And then, the students were given the chances to ask questions as well as comments about direct practice with native speaker.

The third step, during the practice of direct practice with their peers, the researcher observed the students' performance in speaking achievement and also the researcher made some notes of students' mistake in applying direct practice with their peers.

In order to support the strategy, the researcher took two steps; the first was Lesson Plan. It was a road to achieve the goal of teaching learning process. Therefore, it must be arranged in such a way that the activities in the teaching learning process could be aimed at the desired target. This research would focus on improving the students' speaking skill. Thus lesson plan design would be directed to reach the research goal.

Like in general, lesson plan consisted of some items; they were the subject, the topic, time allotment, objectives, material, teaching learning scenario, evaluation/observation, and references. There were three stages in the teaching learning scenario. The stages triggered questions (pre-activity), main activity, and conclusion (post activity). In the triggering questions, the researcher gave some questions to the students about the topic.

While the main activity, the students would be asked to start direct practice about asking and telling the direction. In this stage, teacher determined the place to another place which the students should ask and tell. The first, the students started direct practice with their peers and the one acted as a native speaker while 
the other acted as a student. After getting enough practice with their peer, the student then was asked to have a discussion facilitated by teacher. Every students share what they experienced and felt during conducting direct practice with their peer.

After having a discussion, the next activity was the teacher gave information that the next meeting would be inviting the native speaker to practice with. Here, the students would perform what they had already learned. Here the teacher will observe and evaluate the students' speaking skill whether improve or not. At last, in the conclusion (post activity), the teacher would review the important facts done by the students in the case of speaking aspects development such as; pronunciation, grammar, vocabulary and fluency.

The second is media. The media that have been used in this research was the VCD player, LCD screen, laptop, training sheet, and artificial map. They were used to entice students' attention in to be more active in involving in teaching and learning process. Hopefully, by having some interesting medias, the students would be able to pay more attention to material and increase their speaking skill.

Criteria of success. The criteria of success was based on the result of the observation after the action. It would be considered successful if the mean score of the students could reach the minimum score or KKM of (70) there was an increase in the number of the students who were actively involved in speaking skill performance and they felt more confident to use English. By observing whether the implementation of direct practice with native speaker in teaching speaking succeeded or failed, it was used to decide whether the action has to be continued to the next cycle or stop in cycle I.

\section{Implementation}

To obtain the research goal, the researcher would work together with the native speaker. The job of the native speaker was to give extra information about students' speaking performance during conducting direct practice with him/her. The design of the implementation of direct practice with native speaker technique in this study was presented in the four meetings. 
1. The first meeting, the researcher introduced and explained to the students what direct practice was, and then they are given more motivation to study English more especially in the skill of spoken English.

2. The second meeting, the researcher asked the student to start conducting the direct practice with their peer in the first place.

3. The third meeting, the students started the real direct practice with the native speaker and they had to practice it one by one in front of the class. Then once again, the researcher gave information that the following meeting there would be held a speaking test about telling and asking direction which conducted with the native speaker.

4. The fourth meeting, the students did direct practice with the native speaker and speaking test and the material was different place to another place and it was determined by native speaker.

\section{E. Observation}

For this activity was the process of recording and collecting data, a researcher asked native speaker to observe the activities that existed and done in the class. The researcher and the native speaker observed the implementation of direct practice technique. Some main points were observed: the students' activities and the improvements as well as the students' performance in doing direct practice. To collect an accurate data and to get the reliable result, the researcher prepared the instruments for data collection. In collecting data, the researcher prepared the instrument for data collections with the training sheet.

\section{F. Reflection}

The reflection was done based on the obtained data, if the data met the criteria of success, the action was stopped, but if the criteria of success were not fulfilled, the action will be continued to the next cycle to meet the criteria of success. The conclusion based on the result of the data analysis which refers to the criteria. The criteria of success of direct practicing are; the first is $75 \%$ of students are brave to practice their English with native speakers, and the second is the score given by native speakers on their training sheet. 


\section{G. Result}

To determine the success or fail of the action, the researcher made a reflection and implementation of the action. The reflection was focused on the analysis of the teaching and learning process and the result of the students speaking skill. The analysis was based on the collected data from the post test and training sheet.

In the part the data showed that applying Direct Practice with the Native Speaker technique could increase the students' learning motivation in the teaching and learning process. This could be proved from their well preparation before doing this strategy; it can be seen from the third meeting until the last meeting and also the increasing of the students' speaking skill score.

The application of Direct Practice with the Native Speaker activities is still considered enough difficult to apply in the teaching and learning process for the difficulty to ask the native speaker who have time to come to the school to help out the students with their problems in improving their speaking skill.

Finally, Direct Practice with the Native Speaker can really help the students to have more motivation to learn English more, and the most important thing is that Direct Practice with the Native Speaker can improve students' speaking skill as shown in the third meeting and finally the students succeeded to reach the $\mathrm{KKM}$ of 70.00 in the fourth meeting

In term of the development of the students' speaking skill, after the cycle 1 has done, the data showed that the students' speaking ability was improved and reached the criteria of success. The average score of the speaking test before the treatment was 55,6 the number of student who got the minimum score (70) was only 20 students $(50,7 \%)$ out of 35 students. The other 15 students (49\%) failed. After applying the Direct Practice with Native Speaker technique, the students' speaking skill was improved. All students could reach the criteria of success (70). The highest score obtained by the students was 80 , there were 3 students. The lowest score was 72 , there were 17 students.

Based on explanation above, it is concluded that some improvement was made by applying Direct Practice with the Native Speaker in teaching and learning process. The students also had higher motivation to speak English. Thus, 
there were some aspects of teaching learning strategies needed to be revised and improved in order to achieve the target stated in the criteria of the study. Therefore, the second until the fourth meeting considered the following aspects: 1) The teacher must set the time tightly and effectively in order to make the activities run well as the target, and 2) In order to minimize the domination of the high achiever students, the teacher need to make some modification of the group member and rule the activities.

After considering those aspects, the third and the fourth meeting were run well and could reach the criteria of success. Thus, the action research considered successful, the study is ended.

\section{H. Discussion}

Based on the finding of the research, it could be concluded that the Direct Practice with the Native Speaker needed the teacher to follow a particular procedure in producing a good result of the teaching. The procedure covered the preparation and the implementation. On the preparation, the researcher chose models of activities which were considered appropriate for the teaching to improve the students' speaking ability.

Then, researcher designed a lesson plan in which Direct Practice with the Native Speaker techniques was the main activity. Researcher also created interesting lesson of asking and telling direction as the lesson what the students should learn as one of competencies as stated on syllabus.

At the implementation, researcher provided the students the training sheet as a poof that they had applied and practiced with the native speaker and also they had a score given directly by the native speaker based on their speaking skill. The training sheet gives some advantages to improve speaking skill. First, they can have fun and are motivated to be better in their speaking. Second, the training sheet led the students to a good circumstance of competition among them to have better score than other students.

Based on the researcher's experience in teaching English in Vocational High School, most of the students can rarely use English or some of them do speak English but then the circumstance and the atmosphere do not allow them to 
improve their speaking for communicative objective or most of them had had an idea in their mind but they just do not know the correct way to express their idea in the form of spoken English. This problem may happen because the students are afraid of making some mistakes in practicing English because of some aspects such as; less confidence, lack of idea and vocabulary, have no supported atmospheres or situation to improve their speaking. Based on the above condition, researcher created developed Direct Practice with the Native Speaker technique that is able to be used to allow students to improve their speaking skill.

From the research finding, the researcher found that Direct Practice with the Native Speaker could raise the bravery and motivation of the students to speak their English and give fair competition among students and not to mention the fun atmosphere when they were dealing in a conversation directly with the native speaker.

The proof of Direct Practice with the Native Speaker technique was able to increase the students' speaking skill and active participation in the teaching learning activities can be examined as follows:

1. Direct Practice with the Native Speaker altered the boring activity of teaching and learning English in the classroom into fun atmosphere that the students' speaking skill is improved. The students' score of speaking skill was over the $\mathrm{KKM}$, and the average score was 74, 4.

2. Direct Practice with the Native Speaker brings opportunity for students to experience new concept and atmosphere with their foreign language and it can be showed by the students' activeness on teaching learning activities. The first meeting only 10 students were active, second meeting 12 students as active, third meeting 31 students, the fourth meeting was 35 students or all the students was active.

3. Based on the finding above, the research proved that the implementation of Direct Practice with the Native Speaker could improve the students' speaking skill.

\section{Conclusion}

In teaching speaking by applying Direct Practice with the Native Speaker, the teacher had to do some steps such as: make sure that the native speaker will be 
willing to come to the school to help the students out with their problem in speaking skill. Direct Practice with the Native Speaker offers: fun atmosphere in teaching and learning process, giving the students experience to engage direct conversation with the native speaker, and Direct Practice with the Native Speaker gives good circumstance of competition among the students.

Speaking test conducted after the implementation of Direct Practice with the Native Speaker in the fourth meeting of the first cycle showed that all the students could reach the criteria of success. They passed the minimum mastery learning score or KKM (70) and their average score was 74, 04. This proves that it meets the indicators of successful implementation of the research. Moreover, the implementation of Direct Practice with the Native Speaker shows that students actively involved and highly motivated in learning speaking.

\section{J. Suggestion}

The researcher gives some recommendations concerning to the applying of Direct Practice with the Native Speakerfor teaching speaking:

1. Make sure the native speaker is available for helping the students with their problem of speaking by coming over to the school.

2. Manage the time effectively for conducting the technique,

3. Do not permit the high achiever students to dominate, the teacher should be fair for giving turn students to speak,

4. Gain a reliable test score, it is advisable that the teacher should provide the students with adequate practice.

Related to the future researcher concerning the implementation of Direct Practice with the Native Speaker, researcher recommends trying to make up interactive activities. Hopefully, the future researcher could conduct better researches to help students improving their speaking skill.

\section{References}

Brown, H. D. 2007. Teaching by Principle: An Interactive Approach to Language Pedagogy. California: San Fransisco State University.

Dictionary, O. A. 1995. Oxford Advanced Learner's Dictionary. New York: Oxford University Press. 
Jurnal Darussalam; Jurnal Pendidikan, Komunikasi dan Pemikiran Hukum Islam Vol. IX, No 1: 1-12. September 2017. ISSN: 1978-4767 (Cetak), ISSN: 2549-4171 (Online)

Latief, M. A. 2010. Tanya Jawab Metode Penelitian Pembelajaran Bahasa. Malang: Universitas Negeri Malang (UM PRESS), Meaning of Direct Practice.

Rahmat, J. 2007. Psikologi Komunikasi. Cetakan ke Dua Puluh Empat: PT. Remaja Rosadakarya.

The Adjective Direct Has 10 Senses. Retrieved (from www.audioenglish.net/dictionary/direct.htm direct (adjective). 